\title{
Yabancı Cisim Yutma Öyküsü veya Şüphesi Olan Çocukların Değerlendirilmesi: Tek Merkez Deneyimi
}

\author{
Evaluation of Children with a History of Foreign Body Ingestion \\ or Suspection: A Single Center Experience
}

\author{
Muhammet Akif GÜLER ${ }^{1}$, Ali İ̧LEK ${ }^{2}$, Sultan Tuna AKGÖL GÜR ${ }^{3}$
}

Yazışma Adresi

Correspondence Address

\section{Muhammet Akif GÜLER}

Atatürk Üniversitesi Tip Fakültesi, Çocuk Sağlığı ve Hastalıkları Anabilim Dal, Erzurum, Türkiye

E-posta: akif2532@gmail.com
Geliş tarihi \ Received : 14.05 .2020 Kabul tarihi \ Accepted : 03.07.2020 Elektronik yayın tarihi $\quad: 12.07 .2021$ Online published

Bu makaleye yapılacak atıf: Cite this article as:

Güler MA, İşlek A, Akgöl Gür ST. Yabancı cisim yutma öyküsü veya şüphesi olan çocuklarm değerlendirilmesi: Tek merkez deneyimi. Akd Tip D 2021; 7(2):244-250

Muhammet Akif GÜLER ORCID ID: 0000-0002-3147-6429 Ali İSLEK

ORCID ID: 0000-0001-6172-7797

Sultan Tuna AKGÖL GÜR

ORCID ID: 0000-0002-4490-7267

63. Türkiye Milli Pediatri Kongresi, 30 Ekim - 3 Kasım, 2019 (Poster Bildiri).
'Atatürk Üniversitesi Tıp Fakültesi, Cocuk Sağlığı ve Hastalıkları Anabilim Dalı, Erzurum

${ }^{2}$ Atatürk Üniversitesi Tıp Fakültesi, Çocuk Gastroenteroloji Bilim Dalı, Erzurum

${ }^{3}$ Atatürk Üniversitesi Tip Fakültesi, Acil Tıp Anabilim Dalı, Erzurum öz

Amaç: Yabancı cisim yutma olayları çocukluk döneminin önemli sorunlarından biridir. Bu çalışmada merkezimizin beş yıllık tecrübesi tartışıldı. Olguların yuttukları cisimler ve takip süreçleri, invaziv işlemler, gelişen komplikasyonlar ve kamuya olan maliyetleri geriye dönük olarak incelendi.

Gereç ve Yöntemler: Nisan 2014-Ocak 2019 tarihleri arasında, çocuk acil, erişkin acil ve çocuk gastroenteroloji polikliniklerine yabancı cisim yutma şikayeti ile başvuran 0-18 yaş arası çocuklara ait hasta dosyaları ve hastane otomasyon sistemindeki verileri geriye dönük olarak incelendi.

Bulgular: Yabancı cisim yutma şikayeti ile başvuran 590 olgunun ortalama yaşı 52,8 ay ve 274'ü $(\% 46,4)$ kız idi. Olguların 219'unda $(\% 37,1)$ klinik ve radyolojik olarak yabancı cisim saptanmadı. Hastaların 570'i $(\% 96,6)$ asemptomatik olup en çok yutulan yabancı cisim madeni para $179(\% 30,3)$ idi. Olguların 35’ine $(\% 5,9)$ endoskopik girişim gerekli oldu. İki olguya $(\% 0,3)$ cerrahi işlem yapıldı. Hasta başına ortalama 2,5 konvansiyonel radyografi çekildi. Olguların 47'sine (\%8.0) ise bilgisayarlı tomografi çekildi. Hasta başına kamu maliyetleri ortalama 111,07 TL olarak hesapland.

Sonuç: Yabancı cisim yutma olayları nadiren invaziv işlemlere, radyolojik tetkikler nedeni ile X-ışını maruziyetine ve hastane giderleri nedeni ile kamu harcamalarının oluşmasına neden olmaktadır. Olguların önemli bir bölümünde yabancı cisim saptanamamıştır. En sık yutulan cisimler günlük hayatta kullanılan ve kolay ulaşılabilen cisimler olduğundan ebeveynler tarafindan evde alınacak koruyucu önlemlerle bu sorunun azalacağı öngörülebilir.

Anahtar Sözcükler: Cerrahi, Endoskopi, Konvansiyonel radyografi, Maliyet, Yabancı cisim yutma

\section{ABSTRACT}

Objective: Foreign body ingestions is one of the important issues of childhood. In this study, the five-year experience of our center was discussed. The objects and follow-up processes that the patients ingested, invasive procedures, complications and costs to the public were analyzed retrospectively.

Material and Methods: Data for children aged 0-18 years presenting to pediatric emergency, adult emergency and pediatric gastroenterology units due to foreign body ingestion between April 2014 and January 2019 were examined retrospectively from patient files and the hospital automation system.

Results: The mean age of the 590 children presenting with foreign body ingestion was 52.8 months, and $274(46.4 \%)$ were girls. In clinically and radiologically, no foreign body was detected in 219 $(37.1 \%)$ of the cases. $570(96.6 \%)$ of the patients were asymptomatic and the most commonly ingested objects were coins 179 (30.3\%). Endoscopic procedures were required in $35(5.9 \%)$ of cases. Surgical intervention was performed in two $(\% 0.3)$ cases. A mean of 2.5 conventional radiographs were taken per patient. Computed tomography was performed in $47(8.0 \%)$ of the cases. The mean costs per patient were calculated as 111.07 Turkish Liras.

Conclusion: Foreign body ingestion rarely cause to invasive procedures, x-ray exposure due to radiological imaging, and public costs. Since the most frequently ingested objects are that used in daily life and are easily accessible, it can be predicted that this issue will be reduced by preventive measures to be taken by parents at home.

Keywords: Conventional radiography, Cost, Endoscopy, Foreign body ingestion, Surgery 


\section{GİRIŞ}

Acil servise başvuran hastaların bir kısmını yabancı cisim yutan çocuklar oluşturmaktadır. Cisimleri ağza götürme ve yabancı cisim yutma olayları oyun çocukluğu döneminde daha sık görülür. Yabancı cisim yutma olaylarının büyük bir kısmının fark edilemediği ve tespit edilenden daha fazla yabancı cisim yutma vakası olduğu tahmin edilmektedir $(1,2)$.

En sık yutulan cisimler, madeni para, oyuncak, mıknatıs, yassı pil ve toplu iğnedir (3-5). Bu cisimlerin büyük bir kısmı sorun oluşturmadan kendiliğinden anüsten atılırken az bir kısmı gastrointestinal sistemin (GISS) fizyolojik darlık bölgelerinde takılır $(6,7)$. Yutulan yabancı cisme endoskopik veya cerrahi müdahale gereksinimi, cismin türüne, boyutuna, lokalizasyonuna, hastanın yaşına, klinik semptom oluşturup oluşturmadığına ve cismin yutulduğundan itibaren geçen süreye göre belirlenir. Ancak erişkin rehberlerinin aksine çocukluk dönemi ile ilgili yayımlanan rehberler farklı gelişim çağlarında olan çocuklarda hangi cisimlerin güvenli bir şekilde GİS'ten atılacağı ile ilgili yeterli bilgiler verememektedir (8). Bu konudaki çoğu çalışma yabancı cisim yutan tüm olguların değerlendirilmesinden ziyade invaziv girişim gereken hastaları irdelemiştir $(6,9,10)$.

Bu çalışmada merkezimize yabancı cisim yutma şüphesi veya şikayeti ile başvuran hastaların retrospektif olarak değerlendirilmesi yapılmıştır. Olguların yuttukları cisimler ve takip süreçleri, invaziv işlem gereksinimleri, gelişen komplikasyonlar ve kamuya olan maliyetleri geriye dönük olarak incelendi.

\section{GEREÇ ve YÖNTEMLER}

Nisan 2014-Ocak 2019 tarihleri arasında, Atatürk Üniversitesi Tip Fakültesi Araştırma Hastanesi, çocuk acil, erişkin acil ve çocuk gastroenteroloji polikliniklerine yabancı cisim yutma veya yutma şüphesi ile başvuran çocuk hastalara ait veriler hasta dosyaları ve hastane otomasyon sistemi üzerinden geriye dönük olarak incelendi. Poliklinik kayıt defteri ve hastane otomasyon sistemine ICD (International Statistical Classification of Diseases and Related Health Problems) kodları T18, T18.8 ve T18.9 olarak girilen hastalar çalışmaya dahil edildi. Çalışma, Helsinki Deklarasyon ilkelerine uygun olarak yürütülmüştür. Çalışmamızda araştırma ve yayın etiğine uyulmuştur. Atatürk Üniversitesi Klinik Araştırmalar Etik Kurul'u onayı alındı (13.02.2019 tarih ve karar no:34). Hastaların yaş ve cinsiyetleri, semptomları, tıbbi işlem ve müdahaleler, yutulan cisimlerin türü ve radyografik özellikleri, görüntüleme tetkikleri ve sayıları ile hasta başina ortalama kamu maliyetleri değerlendirildi. Çalışma retrospektif karakterde olduğu için sadece hastanemizde yapilan harcamalara ait maliyetler hesaplanabilmiştir. Tanımlayıcı istatistikler sıklı, oran, ortalama, ortanca ve standart deviasyon olarak verildi.

\section{BULGULAR}

Yabancı cisim yutma şikayeti veya yutma şüphesi ile başvuran 590 olgunun verilerine ulaşıldı. Hastaların yaş

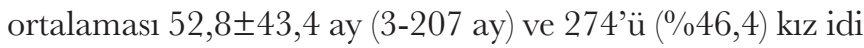
(Tablo I). Beş yüz doksan olgunun dokuzunda $(\% 1,5)$ daha önce de yabancı cisim yutma öyküsü mevcuttu (yedi olgu para, bir olgu bilye ve bir olgu metal cisim).

Olguların başvuru sırasında 570’i (\%96,6) asemptomatik olup, altısı $(\% 1)$ yutma güçlüğü, üçü $(\% 0,5)$ göğüs ağrısı, ikisi $(\% 0,3)$ huzursuzluk, dokuzu $(\% 1,5)$ bulantı, kusma, karın ağrısı, mide ağrısı, ishal, konstipasyon ve öksürük yakınması ile başvurdu.

Olguların tümüne konvansiyonel radyografi $(\mathrm{KR})$ (posterioanterior/lateral akciğer grafisi veya tek/iki yönlü direk karın grafisi) çekilmiş olup, hasta başına ortalama 2,5 KR çekildi. Kırk yedi (\%8.0) olguya ise toraks ve abdomeni içeren bilgisayarlı tomografi (BT) çekildi. Bilgisayarlı tomografi çekilen olguların hiç birinde yabancı cisim tespit edilemedi.

Madeni para yutan 179 hastanın 172'sine herhangi bir invaziv işlem gerekmedi. Madeni 1 TL yutan beş olguya cismin özofagusta takılı kalması ve iki olguya da cisim iki haftadan uzun süredir mideden ilerlemediği için endoskopik işlem uygulandı.

Toplam $31(\% 5,2)$ hasta toplu iğne yutmuş idi. Midede olduğu anlaşlan beş toplu iğnenin dördü endoskopik olarak çıkarılırken birinin mideden ilerlemiş olduğu görüldü. Dikiş iğnesi yutan beş $(\% 0,8)$ hasta vardı. Endoskopik incelemede $4 \mathrm{~cm}$ uzunluğundaki iki adet dikiş iğnesi ve $6 \mathrm{~cm}$ uzunluğundaki bir yorgan iğnesinin mide veya duodenum duvarına invaze olduğu görüldü. Bu cisimler endoskopik olarak çıkarıldılar. Üç dikiş iğnesinin ise GİS’ten kendiliğinden atıldığı gözlendi.

Altı $(\% 1,0)$ hastanın çengelli iğne yuttuğu anlaşıldı. Midede olduğu düşünülen bir çengelli iğnenin endoskopi sırasında ilerlemiş olduğu görüldü. Takipte çengelli iğnelerin tümünün GİS’ten kendiliğinden atıldığı görüldü.

Bu çalışmada özofagusta yassı pil takılı kalan hasta olmadı. Toplam $31(\% 5)$ hastadan beşine pilin mideden ilerlememesi nedeni ile endoskopik çıkarım yapıldı. Bu olgular beş yaşından küçüktü. Endoskopik olarak çıarılan pillerden

Tablo I: Yabancı cisim yutan çocukların yaş aralıkları.

\begin{tabular}{lc}
\hline Yaş aralı̆̆ı & $\mathbf{n}(\mathbf{\%})$ \\
\hline $0-3$ yaş & $274(46,5)$ \\
\hline $4-5$ yaş & $130(22,0)$ \\
\hline $6-10$ yaş & $125(21,2)$ \\
\hline $11-18$ yaş & $61(10,3)$ \\
\hline Toplam & $590(100)$ \\
\hline
\end{tabular}


Tablo II: Yutulan yabanci cisimler.

\begin{tabular}{|c|c|c|}
\hline Yabancı cismin adı & & n $(\%)$ \\
\hline $\begin{array}{l}\text { Tespit edilemeyenler } \\
\text { (Radyografik ve klinik olarak) }\end{array}$ & & $219(37,1)$ \\
\hline Madeni para & & $179(30,3)$ \\
\hline Sivri metaller & $\begin{array}{l}\text { Kapı anahtarı, ataç, çivi, kalem yayı, mermi, metal tel, vida, raptiye, } \\
\text { zımba teli, diş teli, dikiş iğnesi, çengelli iğne, yorgan iğnesi, tel toka }\end{array}$ & $59(10,0)$ \\
\hline Takılar ve oyuncaklar & $\begin{array}{l}\text { Bilye, boncuk, kolye, kolye zinciri, yüzük, küpe, bonibon kapağı, plastik } \\
\text { oyuncak parçası, plastik toka, kalem pil, su maymunu }\end{array}$ & $54(9,2)$ \\
\hline Yassı pil & & $31(5,3)$ \\
\hline Toplu iğne & & $31(5,3)$ \\
\hline Organik maddeler & $\begin{array}{l}\text { Diş, balık kılçı̆̆ı, sinek, bol miktarda zeytin, bol miktarda ay çekirdeği, } \\
\text { kağıt parçası, odun parçası }\end{array}$ & $12(2,0)$ \\
\hline Diğerleri & Süs taşı, cam parçası & $3(0,5)$ \\
\hline Miknatıs & & $2(0,3)$ \\
\hline Toplam & & $590(100)$ \\
\hline
\end{tabular}

Tablo III: Radyografik olarak tespit edilen cisimlerin lokalizasyonları.

\begin{tabular}{lc}
\hline Lokalizasyon & n (\%) \\
\hline Özofagus & $17(5,0)$ \\
\hline Mide & $122(35,6)$ \\
\hline Bağırsak & $203(59,4)$ \\
\hline Toplam & $\mathbf{3 4 2 ( 1 0 0 )}$ \\
\hline
\end{tabular}

birinin çapı $>20 \mathrm{~mm}$ diğerleri ise $<20 \mathrm{~mm}$ idi. Bu olguların dördünde mide mukozasında izlemde komplikasyona neden olmayan yüzeyel erozyonların olduğu görüldü. Kalan 26 olgunun (22'si beş yaşından küçük ve dördü beş yaşından büyük) ise başvuru sırasında ya da anestezi öncesi açlık süreleri beklenirken pillerin bağırsağa geçtiği ve kendiliğinden atıldığı görüldü. Kendiliğinden atılan bu pillerin çapı $<20 \mathrm{~mm}$ idi. Yutulan pillerin tamamı yüksek enerji kaynaklı lityum pildi.

Kötü kokulu ishal ve karın ağrısı nedeni ile başvuran sekiz yaşındaki bir olguda rektal tuşede bol miktarda yabancı cisim (kabuklu ay çekirdeği) izlendi. Enterokolit tanısı da alan olgunun rektumundan impakte olmuş yabancı cisimler manuel olarak çıkarıldı. Otizm tanılı bir diğer olgu ise karın ağrısı ve defekasyona çıkamama nedeni ile başvurdu. Hastaya sedoanaljezi uygulanarak rektal muayene yapilabildi. Olgunun muayenesinde rektuma impakte olduğu anlaşılan yabancı cisimler (çekirdeği çıkarılmamış bol miktarda zeytin) manuel olarak çıkarıldı.

Olguların 371'inde $(\% 62,9)$ görüntüleme yöntemleri ve fizik muayene (rektal tuşe) ile yabancı cisim tespit edildi. Ayrıca olguların $219^{\prime} u(\% 37,1)$ yabancı cisim yutma şüphe- si ile başvurmuş, radyolojik olarak yabancı cisim saptanmamış ve semptomları olmaması nedeni ile de invaziv girişim yapılmamıştır. Yutulan yabancı cisimler (Tablo II)'de gösterilmiştir. Radyoopak cisimlerin saptandığı lokalizasyonlar Tablo III'de gösterilmiştir. Yabancı cisim yutma şikayeti ile getirilen hastaların 35 'ine $(\% 5,9)$ endoskopi yapıldı. Endoskopik ve cerrahi olarak cisimlerin çıkarıldığı bölgeler ve çıkarılan cisimler Tablo IV'te gösterilmiştir.

Bir hastaya yabancı cismin (madeni bir lira) özofagogastrik bileşkede takılı kalması (Resim 1) nedeni ile rijit endoskopi yapıldı. Özofagus mukozasında nekroz ve laserasyonun olduğu görülen olgunun takiplerinde özofagus perforasyonu gelişmesi nedeni ile torakotomi ile primer özofagus onarımı yapıldı. Multiple mıknatıs yutan bir başka olguya da mıknatısların mide ve bağırsak duvarlarını penetre etmesi nedeni ile laparatomi yapıldı (Resim 2).

Olguların 44'ü endoskopik girişim ya da klinik takip amacı ile yataklı serviste izlendi. Bu hastaların hastanede yatış süreleri ortalama 1,82 gün idi. Endoskopik girişim gerektirmeyen ya da endoskopik çıkarımın mümkün olmadığı 546 olguda ise gerekli öneriler yapılarak ayaktan takibi yapıldı. Bu çalışmada yabancı cisim yutan hasta başına düşen ortalama maliyet $111.07 \pm 487,49$ TL olarak hesaplandı.

\section{TARTIŞMA}

Yabancı cisim yutma şikayeti ile sağlık kuruluşlarına başvuran olguların büyük bir kısmını beş yaş altı çocuklar oluşturmaktadır $(8,11)$. Çalışmamızdaki olguların \%68,4'ü literatürle benzer olarak, beş yaş altında idi. Yabancı cisim yutan olgular ailelerinin farkına varması veya çocukların kendi ifadelerine dayanılarak hastaneye getirilmektedir. Bu olguların büyük bir kısmında semptom olmayıp bazen 
Tablo IV: Endoskopi/cerrahi gereken hastalar ve cisimlerin lokalizasyonu.

\begin{tabular}{|c|c|c|c|}
\hline & Lokalizasyon & $\mathbf{n}$ & Gisim \\
\hline \multirow{7}{*}{ Endoskopi } & Özofagus 1. darlık & 5 & $\begin{array}{l}3 \text { adet madeni } 1 \text { TL, } 1 \text { adet küpe, } 1 \text { adet plastik oyuncak } \\
\text { parçası }\end{array}$ \\
\hline & Özofagus 2. darlık & 2 & 1 adet madeni 1 TL, 1 adet saat kordonu \\
\hline & Özofagogastrik bileşke & 2 & 1 adet madeni 1 TL, 1 adet $V$ şeklinde metal tel \\
\hline & Mide & 18 & $\begin{array}{l}5 \text { adet yassı pil, } 4 \text { adet toplu iğne, } 2 \text { adet madeni } 1 \text { TL, } 2 \text { adet } \\
\text { dikiş iğnesi } 1 \text { adet tel toka, } 1 \text { adet kalem pil, } 1 \text { adet mıknatıs, } 1 \\
\text { adet anahtar, } 1 \text { adet küpe }\end{array}$ \\
\hline & $\underline{\text { Post-bulber duodenum }}$ & 3 & 2 adet tel toka, 1 adet yorgan iğnesi \\
\hline & $\begin{array}{l}\text { Duodenum distalinde olup } \\
\text { endoskopi ile çıkarılamayanlar }\end{array}$ & 5 & 3 su maymunu, 1 adet toplu iğne, 1 adet çengelli iğne \\
\hline & Toplam & 35 & \\
\hline \multirow{2}{*}{ Cerrahi } & $\underline{\text { Özofagus }}$ & 1 & 1 adet madeni $1 \mathrm{TL}$ \\
\hline & Ince bağırsak & 1 & 2 adet miknatıs \\
\hline
\end{tabular}
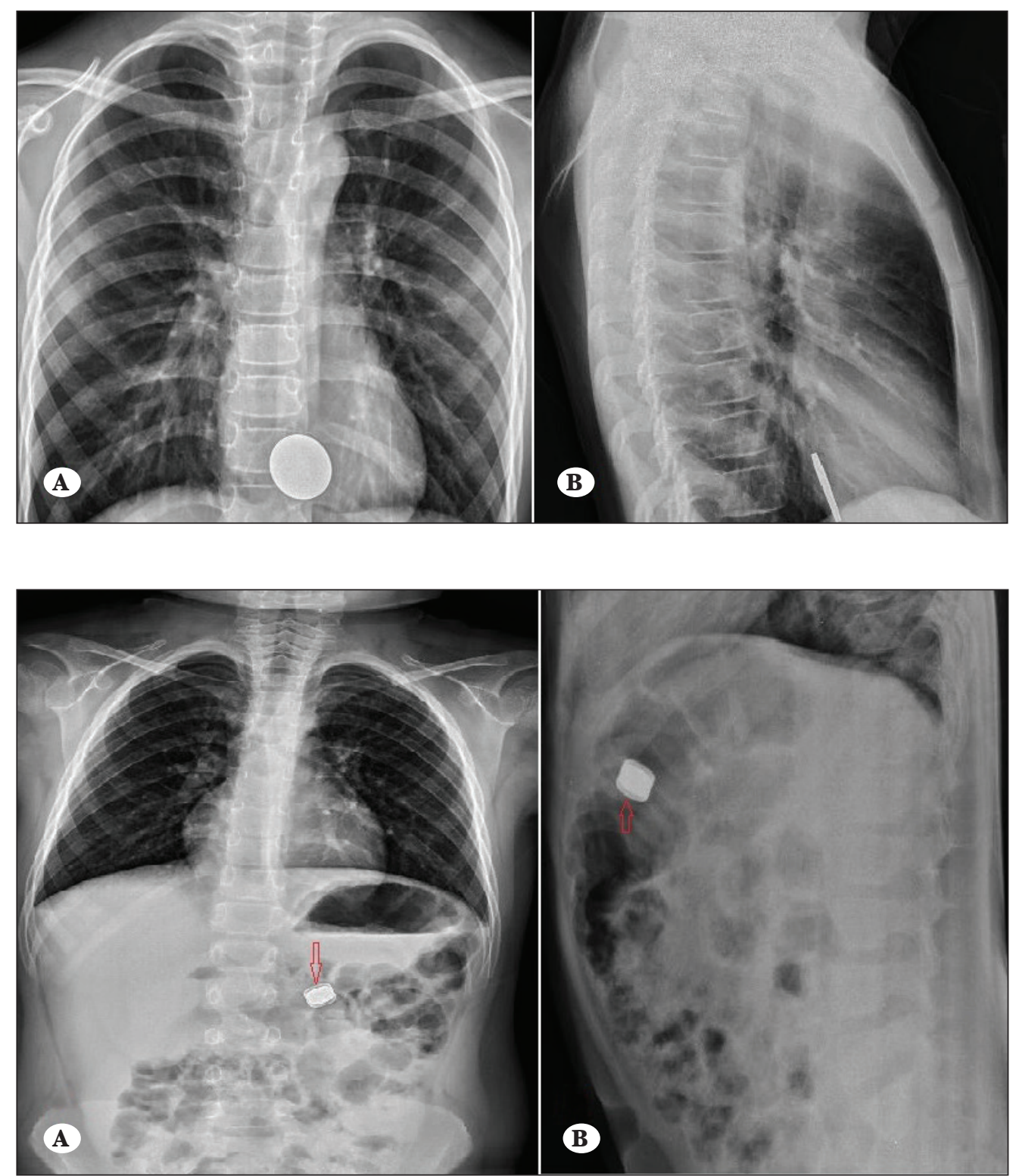

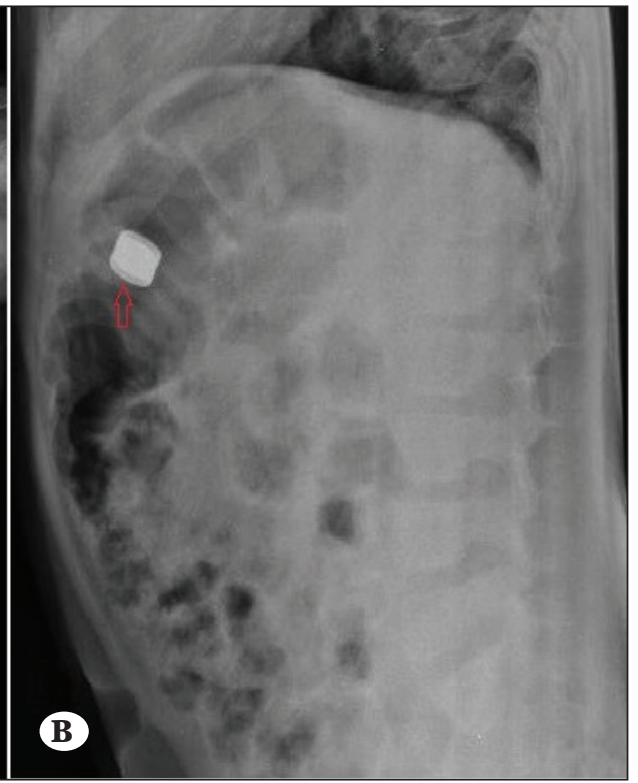

Şekil 1: Özofagogastrik bileşkede takılı kalmış olan madeni para, A) Posterio-anterior akciğer grafisinde, B) Lateral akciğer grafisinde.

Şekil 2: Multiple mıknatıs yutulmasına bağlı mide ve ince bağgrsak duvarının birbirine penetrasyonu. A) Ayakta direk karm gafisinde, B) Lateral karın grafisinde, çift halo işaretine dikkat ediniz (ok). 
yabancı cismin özofagusta takılmasına bağlı olarak disfaji, göğüs ağrısı, kusma gibi özofageal semptomlar görülür $(12,13)$. Bu çalışmada olguların \%96,6'sında başvuru sırasinda herhangi bir semptom olmayip, semptom olanlarda ise en sık yutma güçlüğü gözlendi (\%1). Bu çalışmada olguların \%37,1'i yabancı cisim yutma şüphesi ile başvurmuş ancak bu olgularda yabancı cisme ait bir fizik muayene veya radyolojik kanıt bulunamamıştır. BT inceleme de yabancı cisme ait yararlı bilgiler edinilmemiştir. Bir derlemede yabancı cisimlerin \%35'inin radyoopak olmadığı bildirilmiştir (14). Bu çalışmadaki radyoopak cisim tespit edilmeyen olguların takiplerinde herhangi bir komplikasyon bildirilmemekle birlikte bu cisimlerin hayatı tehdit edici komplikasyon gelişimi yönüyle takip ve değerlendirmelerinin yapılması önemlidir (13).

Yabancı cisim yutma veya yutma şüphesi ile sağlık kuruluşlarına başvuran hastaların herhangi bir semptomu olmasa bile boyundan anüse kadar vücut bölümlerini gösteren KR ile değerlendirilmesi önerilmektedir $(3,12,13)$. Çalışmamızda hasta başına ortalama 2,5 KR çekildiği görüldü. Ancak çalışmamızın retrospektif karakterde olması nedeni ile hastanemize refere edilmeden önce diğer merkezlerde çekilen KR'ler ilgili bilgilere ulaşılamamıştır. Dolayısı ile hesaplanandan daha fazla sayıda KR çekilmiş olduğu düşünülmektedir. Literatürde hasta başına çekilen radyolojik tetkik sayısı ile ilgili bir veriye ulaşılamadı.

Yutulan yabancı cisimler ülke ve bölgelere göre değişmekle birlikte en s1k yutulan yabancı cisimler, madeni paralar $(\% 26,2-\% 58,9)$, diğer metal nesneler (\%11,9-14,2), kemikler $(\% 8,1)$, yassi piller $(\% 2,2-19,5)$, gıda impaksiyonu $\% 6,4$ ve künt cisimler $\% 5,51$ olarak bildirilmiştir $(3,6,15)$. Çalışmamızda en sik yutulan yabancı cisimler de madeni para $(\% 30,3)$ ve metal cisimler $(\% 7,2)$ idi.

Gastrointestinal sistemde takılan cisimlerin çoğu özofagusta tespit edilir $(6,16)$. Güncel çalışmalar özofagusunda yabanc1 cisim tespit edilen hastaların \%4-14'ünde altta yatan özofagus patolojisi veya geçirilmiş özofagus operasyonu olduğunu rapor etmiştir $(15,17)$. Çalışmamızda hastalarda özofagus patolojisi öyküsü yoktu. Özofagustaki cisimlerin obstrüksiyona, özofagus mukozasinda erozyona ve perforasyona yol açma olasılığı bulunduğundan acil olarak çıkarılması önerilmektedir $(3,8,9,12,18)$. Bu çalışmada yabancı cismin özofagusta takılı kalması nedeni ile endoskopik işlem gereken hastaların (9 hasta) birinde özofagusta nekroz ve laserasyon gelişmesi nedeni ile cerrahi işlem gerekli oldu.

Madeni para yutan olguların \%96,0'sına kendiliğinden GÍS'ten atıldıkları için herhangi bir invaziv işlem gerekmedi. Sonuçlarımız madeni paraların özofagusta takılmadığı olgularda konservatif izlemin yerinde bir yaklaşım olacağını göstermektedir.
Özofagusta takılı kalan yassı pillerin ciddi mukoza hasarı yaptıklarından endoskopi ile acil olarak çıkarılmaları gerekmektedir $(8,12)$. Midede saptanan yassı pillerin çapı 20 mm'den küçük, klinik semptom yoksa ve hasta beş yaşından büyükse, konservatif olarak izlenebilir. Çapı 20 mm'den büyük pil yutma durumunda ve hasta beş yaşından küçükse, pil mideye ilerlemiş olsa bile özofagustan geçerken hasar oluşturma ihtimaline karşı endoskopik inceleme gerekliliği değerlendirilmelidir. Bu olgularda endoskopi yapılmadı ise radyografi ile kontrol edilerek 24-48 saat içerisinde pil hala midede ise çıkarılması önerilmektedir (8). Bu çalışmada pil yutan olguların \%5,2'sine pilin mideden ilerlememesi nedeni ile endoskopik çıkarım yapıldı. Bu olguların tamamı beş yaşından küçüktü. Endoskopik olarak çıkarılan pillerden birinin çapı 20 mm'den büyük idi. Endoskopik işlem yapılan beş olgunun dördünde mide mukozasında izlemde komplikasyona neden olmayan yüzeyel erozyonların olduğu görüldü. Çalışmamızın retrospektif karakterde olması nedeni ile pillerin doluluk oranları bilinmediğinden mukozal hasar oluşturma riskleri ile ilgili bir yorum yapılamadı. Ancak olgularımız içinde mide mukozasında erozyon gelişenlerin olması nedeni ile uygun açlık süresi içerisinde pilin midede olduğu değerlendirilen olgulara endoskopi yapilmasının gerekli olduğunu düşünüyoruz.

Çocukların yutabileceği bir diğer yabancı cisim mıknatıstır. Eğer yutulan tek bir mıknatıs ise ve özofagusta takılmadı ise GİS'ten atılımı için izlem prosedürü uygulanır (5). Birden fazla yutulan ve GíS'te ardı sıra giden mıknatıslar farklı GIS segmentlerini birbirine penetre edebilir. Böyle bir durumda basınç nekrozu, ülserasyon, bağırsak perforasyonu ve fistül oluşumu gerçekleşebilir (6). Bu çalışmada mideden ilerlemeyen bir mıknatıs endoskopik yöntemlerle çıkarıldı. Aynı anda iki mıknatıs birden yutan beş yaşındaki olgunun endoskopik ve radyolojik değerlendirmelerinde ince bağırsak ve mide duvarları arasında penetrasyon olduğu görüldü. Endoskopik çıkarımın mümkün olmadığı olguya laparotomi yapılarak mıknatıslar çıkarıldı. Birden fazla mıknatıs yutan olgularda bunların acil olarak endoskopik çıarımı laparotomi gereksinimi ortadan kaldıracaktır.

Çengelli iğneler özofagusta takılı kalmışsa acil olarak çıkarılmalıdır. Midedeki çengelli iğneler bağırsaklarda komplikasyona yol açma riski olduğundan çıkarılmalıdır. Bununla birlikte mideyi geçen çengelli iğneler GíS’ten atılıncaya kadar takip edilebilir $(6,13,19)$. Bu çalışmada endoskopik çıkarımın mümkün olmaması nedeni ile takip edilen çengelli iğnelerin tümünün GíS’ten kendiliğinden atıldığı görüldü.

Su maymunu (superabsorbent products) olarak adlandırdığımız çocuk oyuncakları vücut dışında su ile temas ettiğinde orijinal hacminin onlarca katı büyüklüğe ulaşabilmektedir. Bu cisimlerin yutulması ile GíS'in herhangi bir seviyesinde tıkanma gelişebildiği öne sürülmüştür. $\mathrm{Bu}$ 
nedenle bazı otoritelerce bu olgulara ivedilikle endoskopi yapılması önerilmiştir. Ancak ilk yutulduklarında küçük hacimlerde olan bu cisimlerin GISS içeriği ile temas etme süresi uzadıkça hacimce büyük boyutlara ulaşabildiği ve bu süre içerisinde de pilordan ilerlediği ileri sürülmüştür. $\mathrm{Bu}$ nedenle semptomatik olmayanlara ivedi endoskopik yaklaşım tartı̧ılan bir konu olmuştur (8). Bu çalışmada su maymunu yutma nedeni ile endoskopi yapilan olgularda yabancı cisme rastlanmamıştır. Olguların tümünde cisimlerin herhangi bir semptoma neden olmaksızın GiS'ten kendiliğinden atıldığı gözlenmiştir. Su maymunlarının farklı GIS segmentlerindeki ortam taklit edilerek hacimlerinde meydana gelen değişikliklerinin araştırılması bu hastalara yaklaşımda yararlı bilgiler verebilir.

Mide ve ince bağırsaktaki iğne gibi sivri cisimlerin komplikasyona sebep olma riski nedeni ile acil olarak çıkarılması önerilir $(8,13)$. Çalışmamıda toplu iğnelerin $\% 87,1$ ’i ve dikiş iğnelerinin \%60'ı için endoskopik çıkarım mümkün olmamış ve komplikasyon gelişmeyerek kendiliğinden GíS'ten atılmıştır. Bu sonuçlarla birlikte azımsanmayacak oranda mide ve duodenum mukozasına penetre dikiş ve yorgan iğnesinin olması, diğer intestinal segmentlerde de penetrasyonun gerçekleşme olasılığı nedeni ile acil çıkarımin önemini vurgulamak isteriz.

Literatüre göre yabancı cisim yutma olaylarında endoskopik girişim gereksinimi $\% 2-20$, cerrahi gereksinimi ise \%1-2 oranında değişmektedir $(4,6,7,9,10)$. Çalışmamızda olguların \%5,9'una endoskopik girişim ve $\% 0,3$ 'üne ise cerrahi müdahale yapıldı. Merkezimizde fleksible endoskopi uygulamalarının yaygın olarak yapılmasının komplikasyon gelişme oranlarını azalttığını düşünüyoruz.

Çalışmamızda künt cisim yutan hastaların 3-10 yaş, sivri cisim yutanların ise 10-18 yaş aralığında yoğunlaştığı görüldü. Bu çalışmada oyuncak parçası, madeni para ve benzeri metal cisimlerin sıklıkla küçük çocuklar, iğnelerin ise (sıklıkla başörtüsü bağlamada kullanılan) adölesanlar tarafindan yutulduğu görüldü. Bu sonuçlar bize yabancı cisim yutma olaylarından sadece küçük çocukların etkilenmediğini, yaptıklarını idrak etme yetenekleri daha yüksek olan adölesanların da toplu iğne gibi yabancı cisimleri ağızlarında bulundurmamaları gerektiğini göstermektedir.

Enterokolit tanısı alan psikomotor gelişimi normal olan bir olgu ile karın ağrısı ve kabızlık yakınması olan otizm tanılı bir olguda yabancı cisim yutma öyküsü alınamadı. Radyolojik değerlendirmelerinde de bir özellik saptanmayan bu olguların rektal tuşelerinde organik yabancı cisimlere rastlanıldı. Bu vakalardan yola çıkılarak fizik muayenenin bir parçası olarak rektal tuşenin önemini vurgulamak isteriz.
$\mathrm{Bu}$ çalışmada olguların \%1,5’inde tekrarlayan yabancı cisim yutma öyküsünün olduğu görüldü. Bu olgulardan birinin mental retardasyonu vardı. Tekrarlayan yabancı cisim yutma ve mental rahatsızlık birlikteliğini vurgulayan çalışmalar mevcuttur $(20,21)$. Bununla birlikte tüm yabancı cisim yutan olgularımızın sadece ikisinde mental retardasyon vardı. Yabancı cisim yutan olguların ebeveynlerinin büyük bir kısmı bizlere, çocuklarının yabancı cisim yutacaklarını düşünmedikleri için önlem alma gereği hissetmediklerini aktarmaktadırlar. Bu sebeple çocuklarının mental durumlarına bakmaksızın, ebeveynler koruyucu önlemlerin alınmasında daha hassas davranmalıdırlar.

Hastaların kamuya olan maliyetlerinin hasta başına ortalama 111.07 TL olduğu tespit edildi. Ailenin ulaşım giderleri, il dışından gelen hastaların ulaşım ve beslenme giderleri, ailelerin iş gücü kayıpları da dikkate alındığında, gerçek maliyetin verilen bu ortalama maliyetin çok daha üzerinde olduğu aşikardır.

\section{SONUÇ}

Yabancı cisim yutma bazen hayatı tehdit eden sağlık sorunlarına neden olabilmekte, hastalar X-1şınlarına ve invaziv işlemlere maruz kalabilmektedir. Çalışmaya alınan vakaların \%37,l'inde yutulan cisimler muayene ve görüntüleme yöntemleri ile tespit edilememiştir. Ayrıca yabancı cisim yutan çocukların büyük bir kısmına $(\% 93,3)$ girişimsel işlem gerekmemiş ve cisimler GiS'ten kendiliğinden atılmıştır. En sık yutulan cisimlerin günlük hayatta en ssk kullanılan cisimler olduğu göz önünde bulundurulduğunda, evde alınacak koruyucu önlemler hakkında ebeveynlerin bilgilendirilmesine yönelik faaliyetlerde bulunulması yararlı olacaktır.

Çıkar Çatışması: Tüm yazarlar çıkar çatışması olmadığını beyan eder.

Finansman veya Mali Destek: Bu çalışma için ve makalenin hazırlanmasında herhangi bir bütçe kullanılmamış ve mali destek alınmamıştır.

\section{Yazarların Katkısı:}

Çalışmanın konsepti ve dizaynı: MAG, AI

Verilerin toplanması ve işlenmesi: MAG, STAG

Verilerin analizi ve yorumlanması: MAG, AI

Literatür araştırması: MAG, AI

Makalenin yazımı: MAG, AI

Kritik gözden geçirme: MAG, AI, STAG 


\section{KAYNAKLAR}

1. Dereci S, Koca T, Serdaroğlu F, Akçam M. Foreign body ingestion in children. Turk Pediatri Ars 2015;50:234-40.

2. Wright CG, Closson FT. Updates in pediatric gastrointestinal foreign bodies. Pediatr Clin North Am 2013;60:1221-39.

3. Bolton SM, Saker M, Bass LM. Button battery and magnet ingestions in the pediatric patient. Gurr Opin Pediatr 2018;30:653-59.

4. Kay M, Wyllie R. Pediatric foreign bodies and their management. Curr Gastroenterol Rep 2005;7:212- 8.

5. Waltzman ML, Baskin M, Wypij D, Mooney D, Jones D, Fleisher G. A randomized clinical trial of the management of esophageal coins in children. Pediatrics 2005;116:6149.

6. Erginel B, Karlı G, Gün Soysal F,Keskin E, Özbey H, Çelik A, Salman T. Çocukluk çağında yabancı cısım yutma. İst Tip Fak Derg 2016;79:27-31.

7. Wahbeh G, Wyllie R, Kay M. Foreign body ingestion in infants and children: location, location, location. Clin Pediatr (Phila) 2002;41:633 40.

8. Kramer RE, Lerner DG, Lin T, Manfredi M, Shah M, Stephen TC, Gibbons TE, Pall H, Sahn B, McOmber M, Zacur G, Friedlander J, Quiros AJ, Fishman DS, Mamula P. Management of Ingested Foreign Bodies in Children: A Clinical Report of the NASPGHAN Endoscopy Committee. J Pediatr Gastroenterol Nutr 2015;60:562-74.

9. Özaydın S, Erol M, Çelebi S, Başdaş CB, Güvenç Ü, Sander S. Yutulan Yabancı Cisimlerin Oluşturduğu Gastrointestinal Cerrahi Sorunlar. IKSST Derg 2016;8:10610.

10. Tiryaki HT, Akbıyık F, Şenel E, Mambet E, Livanelioğlu Z, Atayurt HF. Çocukluk çağında yabancı cisim yutulmas1. Türkiye Çocuk Hast. Derg 2010;4:94-9.

11. Gummin DD, Mowry JB, Spyker DA, Brooks DE, Fraser MO, Banner W. 2016 Annual Report of the American Association of Poison Control Centers' National Poison Data System (NPDS): 34th Annual Report. Clin Toxicol (Phila) 2017; 55(10): 1072-252.
12. Wright CG, Closson FT. Updates in Pediatric Gastrointestinal Foreign Bodies. Pediatr Clin N Am 2013;60:122139.

13. Manfredi M. Caustic Ingestion and Foreign Bodies. In Wyllie R, Hyams JS, Kay M, eds. Pediatric gastrointestinal and liver disease. Fifth edition. Chapter 18. Philadelphi, Elsevier, 2016:206-21.

14. Arana A, Hauser B, Hachimi-Idrissi S, Vandenplas Y. Management of Ingested Foreign Bodies in Childhood and Review of the Literature. Eur J Pediatr 2001;160:46872.

15. Ibrahim AH, Andijani A, Abdulshakour M, Algain S , Thamrah AA, Ali MM, Marwah H, Aldaher A, Bashir S, Alsaleem B, Asery A, Al-Hussaini A. What Do Saudi Children Ingest? A 10-Year Retrospective Analysis of Ingested Foreign Bodies From a Tertiary Care Center. Pediatr Emerg Care 2019;24:1-7.

16. Uyemura MC. Foreign body ingestion in children. Am Fam Physician 2005;72:287-91.

17. Louie JP, Alpern ER, Windreich RM. Witnessed and unwitnessed esophageal foreign bodies in children. Pediatric Emergency Care 2005;2 1:582-85.

18. Heim SW, Maughan KL. Foreign bodies in the ear, nose, and throat. Am Fam Physician 2007;76:1185-9.

19. Gün F, Salman T, Abbasoglu L, Celik R, Celik A. Safetypin ingestion in children: a cultural fact. Pediatric Surgery International 2003;19:482-84.

20. Grimes JC, Spier BJ, Swize LR, Lindstrom MJ, Pfau PR. Predictors of Recurrent Ingestion of Gastrointestinal Foreign Bodies. Can J Gastroenterol 2013; 27: e1-e4.

21. Low Kapalu CM, Ibrahimi N, Mentrikoski JM, Attard T. Pediatric Recurrent Intentional Foreign Body Ingestion: Case Series and Review of the Literature J Pediatr Gastroenterol Nutr 2020; doi: 10.1097/ MPG.0000000000002757. 